\title{
Analisis In Silico Aktivitas Antimikroba Peptida dari Susu Kuda Sumbawa
}

\section{(In Silico Analysis of Antimic robial Activity of Peptides from Sumbawa Mare Milk)}

\author{
Kusumaningtyas E, Subekti DT \\ Balai Besar Penelitian Veteriner, Jl RE Martadinata 30 Bogor \\ enikusuma@yahoo.com
}

\begin{abstract}
Microorganisms that are resistant to various drugs remains a serious problem for human and livestock around the world when the conventional drugs loss their activity against to the microbial target. Antimicrobial peptide represents a promising alternative to combat the pathogens. The aims of this study was to evaluate the antimicrobial activity of the peptides derived from Sumbawa mare milk protein using in silico analysis. Peptide LVNELTEFAK, HPYFYAPELLYYANK and LANSTEFAK were analyzed in silico using softwares to predict their potency as antimicrobia. The result of in silico analysis showed that different software produce various prediction of antimicrobial activity. Most of software used predicted that peptide LVNELTEFAK, HPYFYAPELLYYANK and LANSTEFAK were not categorized as antimicrobial peptides. Although those peptides showed higher therapeutic index prediction than Cecropin A but they showed less inhibition activities against Escherichia coli and Candida albicans. It was concluded that more than one software was needed to obtained more accurate prediction. This result is able to use as basic for screening, designing and finding new antimicrobia.
\end{abstract}

Key words: In silico, peptide, antimicrobial activity

\begin{abstract}
ABSTRAK
Mikroorganisme yang resisten terhadap berbagai obat masih menjadi masalah yang serius bagi manusia dan ternak di dunia ketika obat-obat konvensional kehilangan aktivitasnya terhadap mikroba target. Peptida antimikroba sebagai alternatif yang cukup menjanjikan untuk menghadapi mikroba patogen tersebut. Tujuan dari penelitian ini adalah untuk mengevaluasi aktivitas antimikroba peptida derivat protein susu kuda Sumbawa dengan analisis in silico. Peptida LVNELTEFAK, HPYFYAPELLYYANK dan LANSTEFAK dianalisis secara in silico menggunakan perangkat lunak untuk memprediksi potensinya sebagai antimikroba. Hasil analisis in silico menunjukkan bahwa perangkat lunak yang berbeda menghasilkan prediksi aktivitas antimikroba yang berbeda. Hampir semua perangkat lunak yang digunakan memprediksi peptida LVNELTEFAK, HPYFYAPELLYYANK dan LANSTEFAK bukan merupakan peptida antimikroba. Walaupun peptida-peptida tersebut menunjukkan indek terapi prediksi yang lebih tinggi daripada Cecropin A, sebagai peptida kontrol, tetapi peptida-peptida tersebut menunjukkan aktivitas penghambatan yang lebih kecil terhadap Escherichia coli dan Candida albicans. Berdasarkan hasil tersebut dapat disimpulkan bahwa diperlukan lebih dari satu perangkat lunak untuk memperoleh prediksi yang lebih akurat. Hasil penelitian ini juga dapat digunakan sebagai dasar untuk skrining, desain dan penemuan antimikroba baru.
\end{abstract}

Kata kunci: In silico, peptida, aktivitas antimikroba 


\section{PENDAHULUAN}

Resistensi mikroba terhadap obat-obatan atau antibiotika konvensional masih menjadi masalah global seiring dengan menurunnnya kemampuan antibiotika untuk membunuh mikroba target. Kecepatan penemuan antibakteri dan antifungi baru tidak mampu mengimbangi laju resistensi mikroba yang semakin meningkat baik jenis maupun jumlahnya. Peptida menarik perhatian dalam dekade terakhir karena aktivitasnya sebagai antimikroba dengan spektrum yang luas. Mekanisme kerja yang berbeda dengan antibiotika konvensional mengurangi kemungkinan peptida untuk menimbulkan resistensi (Marr et al. 2006).

Seperti produk alami lain, peptida memerlukan skrining untuk mendapatkan aktivitas yang diinginkan. Pengujian laboratorium memerlukan tenaga waktu dan biaya yang sangat besar sehingga diperlukan strategi yang lebih murah dan cepat. Metode komputasi dikembangkan untuk mempercepat proses skrining, penemuan dan desain kandidat antimikroba (Badra et al. 2018). Beberapa perangkat lunak dibuat untuk memprediksi aktivitas antimikroba. Skrining dapat dilakukan berdasarkan urutan asam amino, hidrofobisitas, muatan dan amphiphatisitas yang merupakan penentu aktivitas antimikroba. Sifat fisiko-kimia sekuen peptida yang akan diuji akan dibandingkan dengan peptida yang sudah diketahui aktivitas antimikrobanya di database. Berdasarkan kemiripan sifat fisikokimia tersebut dapat diprediksi aktivitas antimikrobanya.

Beberapa perangkat lunak bahkan menawarkan pilihan untuk modifikasi peptida untuk meningkatkan aktivitasnya, memperkirakan bentuk atau model, interaksi elektrosatik, tegangan permukaan dan dinamika molekuler untuk memprediksi aktivitasnya (Cantor et al. 2019). Perangkat lain memprediksi konformasi akibat pengaruh lingkungan dan skrining berdasarkan kemiripan struktur.

Meskipun perangkat lunak mampu memprediksi aktivitas suatu peptida tetapi hanya digunakan untuk membantu skrining. Setelah mendapatkan peptida terpilih sesuai dengan yang diinginkan peptida tersebut harus diuji aktivitasnya di laboratorium. Pada penelitian ini peptida yang digunakan berasal dari fraksi $<3 \mathrm{kDa}$ hidrolisat susu kuda. Fraksi tersebut mengandung 13 peptida yang berbeda yang selanjutnya diskrining untuk mendapatkan peptida dengan indeks terapi tinggi yang diperkirakan mempunyai aktivitas antimikroba yang tinggi pula. Peptida terpilih tersebut selanjutnya diprediksi aktivitasnya menggunakan beberapa perangkat lunak yang berbeda. Tujuan dari penelitian ini adalah untuk mengevaluasi aktivitas antimikroba peptida derivat protein susu kuda Sumbawa dengan analisis in silico menggunakan beberapa perangkat lunak yang berbeda.

\section{MATERI DAN METODE}

\section{Peptida}

Peptida yang digunakan berasal dari peptida yang diperoleh dari penelitian sebelumnya (Kusumaningtyas et al. 2016). Susu kuda Sumbawa dihidrolisis menggunakan protease Bacillus thuringiensis. Hidrolisat yang diperoleh difraksinasi secara bertingkat menggunakan membrane molecular weight cut off (MWCO) $3 \mathrm{kDa}$. Fraksi yang diperoleh disekuensing menggunakan LCMS/MS sehingga diperoleh 13 peptida. Selanjutnya dipilih peptida dengan indeks terapi tinggi yaitu peptida 1: LVNELTEFAK, peptida2: HPYFYAPELLYYANK dan peptida 3 sebagai hasil 
modifikasi peptida 1 dengan mengganti asam amino $\mathrm{V}$ menjadi A dan E menjadi S: LANSLTEFAK. Sebagai kontrol peptida digunakan Cecropin A: KWKLFKKIEKVGQNIRDGIIKAGPAVAVVGQATQIAK.

\section{Analisis peptida}

Analisis in silico merupakan suatu analisis untuk menggambarkan performa suatu bahan melalui simulasi komputer. Biasanya dilakukan untuk menggambarkan sistem biologi. Eksperimen di bidang biologi molekuler dengan menggunakan data yang banyak seperti skrining membutuhkan biaya yang besar sehingga analisis komputasi sangat membantu memprediksi hasil sehingga ekperimen laboratorium tidak perlu dilakukan semuanya.Peptida terpilih dianalisis menggunakan Antimicrobial peptide scanner Vr2 (https://www.dveltri.com/ascan/v2) (Veltri et al. 2018), antimicrobial peptide database (http://aps.unmc.edu/AP/) (Wang et al. 2016), iAMPpred (cabgrid.res.in:8080/amppred/server.php) (Meher et al. 2017) dbAMP (http://csb.cse.yzu.edu.tw/dbAMP) (Jhong et al. 2018) dan http://www.camp.bicnirrh.res.in/predict/ (Waghu et al. 2015), indeks terapi diprediksi menggunakan http://split4.pmfst.hr/split/dserv1/ (Juretic et al. 2009).

\section{HASIL DAN PEMBAHASAN}

Peptida yang digunakan pada penelitian ini diperoleh dari hasil penelitian sebelumnya dengan hasil analisis fisikokimia sebagai berikut:

Tabel 1. Analisis fisikokimia dan indeks terapi peptida

\begin{tabular}{lcccccc}
\hline \hline Sekuen & $\begin{array}{c}\text { Pjg } \\
(\mathrm{aa})\end{array}$ & $\begin{array}{c}\text { Mass } \\
(\mathrm{Da})\end{array}$ & TI & Muatan & $\begin{array}{c}\text { Hidrofobisitas } \\
(\mathrm{kkal} / \mathrm{ml})\end{array}$ & ITp \\
\hline LVNELTEFAK & 10 & 1162.62 & 6,53 & -1 & $+14,89$ & 28,68 \\
HPYFYAPELLYYANK & 15 & 1887.92 & 7,47 & 0 & 11,74 & 64,75 \\
LANSLTEFAK & 10 & 1092.58 & 6,53 & 0 & $+12,68$ & 94,91 \\
KWKLFKKIEKVGQNIRDGII & 37 & 4003.80 & 10,94 & +6 & $+34,74$ & 31,83 \\
$\begin{array}{l}\text { KAGPAVAVVGQATQIAK } \\
\text { (Cecropin A; peptida }\end{array}$ & & & & & & \\
komersial) & & & & & & \\
\hline
\end{tabular}

Sumber: Kusumaningtyas et al. 2016; Cecropin A data sheet

TI: titik isoelektrik; ITp: indeks terapi prediksi

Aktivitas peptida antimikroba biasanya terutama ditentukan oleh muatan dan hidrofobisitas. Muatan positif diperlukan ketika peptida mulai menempel pada membran bakteri yang biasa bermuatan negatif selanjutnya hidrofobisitas menentukan kemampuan untuk membuat lubang pada membran dan masuk ke dalam sel mikroba target (Henriksen et al. 2014). Seperti terlihat pada Tabel 1, muatan peptida LVNELTEFAK, HPYFYAPELLYYANK dan LANSTEFAK negatif dan netral, sedangkan Cecropin A bermuatan positif. Demikian pula hidrofobisitas Cecropin A lebih tinggi daripada ketiga peptida tersebut. Berdasarkan muatan dan hidrofobisitas tersebut diprediksi aktivitas antimikroba ketiga peptida lebih rendah dibandingkan 
dengan Cecropin A. Cecropin A adalah peptida yang sudah dipasarkan meskipun belum digunakan untuk terapi dalam bidang medis.

Indeks terapi merupakan parameter yang menyatakan spesifitas antimikroba. Indeks terapi dihitung berdasarkan rasio aktivitas antimikroba dan aktivitas hemolitik (Huang et al. 2014). Indeks terapi tinggi menggambarkan aktivitas antimikroba yang tinggi dengan toksisitas rendah. Pada penelitian ini, indeks terapi prediksi (ITp) diperoleh berdasarkan hasil analisis oleh perangkat lunak berdasarkan sekuen dan aktivitasnya terhadap bakteri E. coli. ITp ketiga peptida lebih tinggi dibandingkan dengan Cecropin A sebagai peptida kontrol. Untuk mendapatkan indeks terapi yang sebenarnya perlu dilakukan uji laboratorium untuk mendapatkan data toksisitas dan hemolisis. Analisis menggunakan antimicrobial peptide database (http://aps.unmc.edu/AP/) juga menunjukkan bahwa peptida LVNELTEFAK, HPYFYAPELLYYANK dan LANSTEFAK mempunyai peluang sebagai antimikroba (Tabel 2). Pada perangkat lunak ini sekuen peptida diidentifikasi dan dikalkulasi asam amino hidrofobik dan kemampuannya peptida untuk membentuk heliks. Struktur heliks diperlukan peptida dalam aktivitasnya sebagai antimikroba dan berikatan dengan membran sel target (Fernandez-Vidal 2008; Huang et al. 2010).

Berdasarkan sekuennya, peptida tersebut diprediksi dapat berinteraksi dengan membran sel target yang memungkinkan ketiga peptida tersebut dapat menjadi antimikroba. Sekuen peptida dibandingkan kemiripannya dengan yang ada dalam database untuk menentukan bahwa peptida tersebut mempunyai potensi sebagai antimikroba atau tidak. Cecropin A sudah masuk ke dalam database antimikroba sehingga langsung dikenali sebagai antimikroba

Prediksi aktivitas antimikroba juga dapat menggunakan Antimicrobial peptide scanner ver 2. Hasil analisis peptida LVNELTEFAK, HPYFYAPELLYYANK dan LANSTEFAK menggunakan Antimicrobial peptide scanner ver 2. seperti terlihat pada Tabel 3.

Berdasarkan hasil analisis sekuen pada Table 3, ketiga peptida tersebut tidak termasuk dalam peptida antimikroba sedangkan Cecropin A masuk dalam kelompok antimikroba. Perangkat ini hanya mampu memprediksi kemungkinan sekuen peptida atau protein menjadi antimikroba yang aktif terhadap bakteri Gram positif atau Gram negatif tetapi tidak dapat digunakan untuk memprediksi aktivitasnya terhadap fungi dan virus (Veltri et al. 2018).

Analisis selanjutnya menggunakan iAMPpred. Perangkat tersebut menggunakan Support vector machine (SVM) untuk memprediksi suatu peptida merupakan antimikroba atau non antimikroba berdasarkan teknik bioinformatika dan statistik. Database dalam perangkat ini disusun dari database perangkat yang telah ada sebelumnya, yaitu koleksi peptida antibakteri, antivirus dan antifungi serta beberapa peptida yang tidak termasuk antimikroba. Menurut Meher et al. (2017) input SVM berasal dari komposisi asam amino, sifat fisikokimia dan struktur peptida yang selanjutnya digunakan untuk memprediksi aktivitas antimikroba peptida. Pendekatan tersebut diklaim mampu meningkatkan akurasi prediksi dibandingkan dengan pendekatan lain yang telah ada sebelumnya. Hasil prediksi menggunakan iAMPpred seperti terlihat pada Tabel 4.

Seperti terlihat pada Tabel 4, peptida LVNELTEFAK, HPYFYAPELLYYANK dan LANSTEFAK diprediksi bukan termasuk dalam peptida antimikroba sedangkan Cecropin A masuk kategori peptida antimikroba karena nilainya mendekati 1,00. Semakin tinggi nilai yang diperoleh semakin tinggi aktivitas antimikrobanya. Peptida 
LANSTEFAK yang merupakan hasil modifikasi peptida LVNELTEFAK yang sebelumnya diprediksi meningkatkan index terapi dan aktivitas antimikrobanya, pada analisis ini LANSTEFAK diprediksi meningkat aktivitasnya dibandingkan dengan LVNELTEFAK meskipun belum dapat dimasukkan dalam kategori peptida antimikroba (Kamech et al. 2012; Kusumaningtyas et al. 2016).

Tabel 2. Analisis peptida menggunakan antimicrobial peptide database

\begin{tabular}{ll}
\hline \hline Sekuen & Kemungkinan sebagai Antimikroba \\
\hline LVNELTEFAK & Mungkin sebagai antimikroba \\
HPYFYAPELLYYANK & Mungkin sebagai antimikroba \\
LANSLTEFAK & Mungkin sebagai antimikroba \\
KWKLFKKIEKVGQNIRDGII & Peptida antimikroba \\
KAGPAVAVVGQATQIAK & \\
\hline
\end{tabular}

Tabel 3. Analisis peptida menggunakan Antimicrobial peptide scanner ver 2

\begin{tabular}{lcc}
\hline \hline Sekuen & Kelas (AMP, non AMP & Kemungkinan \\
\hline LVNELTEFAK & Non AMP & 0,0259 \\
HPYFYAPELLYYANK & Non AMP & 0,0727 \\
LANSLTEFAK & Non AMP & 0,2567 \\
KWKLFKKIEKVGQNIRDGII & AMP & 1,0 \\
KAGPAVAVVGQATQIAK & & \\
\hline
\end{tabular}

AMP: antimicrobial peptide; peptida antimikroba

NAMP: tidak termasuk peptida antimikroba

Tabel 4. Analisis peptida menggunakan iAMPpred

\begin{tabular}{lccc}
\hline \hline Sekuen & Antibakteri & Antivirus & Antifungi \\
\hline LVNELTEFAK & 0,025 & 0,077 & 0,019 \\
HPYFYAPELLYYANK & 0.13 & 0,22 & 0,11 \\
LANSLTEFAK & 0,14 & 0,36 & 0,29 \\
KWKLFKKIEKVGQNIRDGII & 0,99 & 0,84 & 0,98 \\
KAGPAVAVVGQATQIAK & & & \\
\hline
\end{tabular}

Analisis selanjutnya menggunakan $\mathrm{CAMP}_{\mathrm{R} 3}$ (Collection of anti-microbial peptides) dibuat untuk mengembangkan dan mempercepat penelitian mengenai kelompok peptida antimikroba. Peptida antimikroba mempunyai kelompok-kelompok yang masing-masing mempunyai persamaan komposisi sekuen spesifik yang dapat mengarahkan penemuan peptida antimikroba yang baru. Database pada perangkat ini memungkinkan perbandingan antara peptida dan pencarian motif atau model tertentu (Waghu et al. 2015).

Berdasarkan analisis menggunakan $\mathrm{CAMP}_{\mathrm{R} 3}$, peptida LVNELTEFAK, HPYFYAPELLYYANK dan LANSTEFAK juga diprediksi bahwa ketiganya bukan termasuk peptida yang mempunyai aktivitas antimikroba atau aktivitasnya rendah. 
Cecropin A, seperti pada prediksi menggunakan perangkat lunak sebelumnya, termasuk dalam kelompok peptida antimikroba. Dari 4 perangkat lunak yang digunakan pada penelitian ini hanya 1 yang menyatakan ketiga peptida mempunyai kemungkinan sebagai peptida antimikroba. Banyak pilihan perangkat lunak yang dapat digunakan baik yang berbayar maupun tidak berbayar yang tersedia secara online. Masing-masing perangkat lunak mempunyai kelebihan dan kekurangan sehingga untuk mendapatkan prediksi yang akurat perlu digunakan lebih dari satu perangkat.

Tabel 5. Analisis peptida menggunakan Koleksi peptida antimikroba $\left(\mathrm{CAMP}_{\mathrm{R} 3}\right)$

\begin{tabular}{lcccc}
\hline \hline Sekuen & SVM & $\begin{array}{c}\text { Random } \\
\text { Forest }\end{array}$ & ANN & $\begin{array}{c}\text { Discriminant } \\
\text { Analysis }\end{array}$ \\
\hline LVNELTEFAK & 0,008 & 0,4035 & NAMP & 0.016 \\
HPYFYAPELLYYANK & 0,010 & 0,037 & & (NAMP) \\
LANSLTEFAK & (NAMP) & $($ NAMP) & & 0,004 \\
& 0,0017 & 0,2865 & NAMP & (NAMP) \\
KWKLFKKIEKVGQNIRDGII & 0,987 & 0,9995 & AMP & 0,026 \\
KAGPAVAVVGQATQIAK & $($ AMP) & $($ AMP) & (AMP) & (AMP) \\
\hline
\end{tabular}

SVM: Support Vector Machine

ANN: Artificial Neural Network

Untuk mengetahui keakuratan prediksi perangkat lunak tersebut, peptida LVNELTEFAK, HPYFYAPELLYYANK dan LANSTEFAK disintesis dan selanjutnya diuji aktivitas antibakteri dan antifungi terhadap Escherichia coli dan Candida albicans. Hasil uji aktivitas menunjukkan bahwa peptida tunggal hanya mampu menurunkan dari konsentrasi kapang dan khamir dari konsentrasi awal $10^{5}$ CFU/mL menjadi $10^{4}-10^{3}$ $\mathrm{CFU} / \mathrm{mL}$ (Kusumaningtyas et al. 2019). Hasil tersebut masih lebih rendah dibandingkan dengan aktivitas antifungi fraksi $<3 \mathrm{kDa}$, fraksi yang merupakan asal peptida-peptida tersebut sebelum dimurnikan menjadi peptida tunggal. Sesuai dengan prediksi menggunakan 3 perangkat lunak terakhir yaitu antimicrobial peptide scanner ver 2, iAMPpred dan $\mathrm{CAMP}_{\mathrm{r} 3}$, ketiga peptida mempunyai aktivitas antibakteri dan antifungi yang kecil sehingga belum dapat dimasukkan dalam kelompok peptida antimikroba. Sebaliknya kontrol peptida Cecropin A terbukti mempunyai aktivitas antibakteri dan antifungi yang baik terlihat dari kemampuannya untuk menghambat pertumbuhan $E$. coli dan C. albicans dan menurunkan jumlahnya dari 9,6 x $10^{5}$ dan 6,9 x $10^{5} \mathrm{CFU} / \mathrm{ml}$ menjadi 0 (Kusumaningtyas et al. 2019).

Mengingat bahwa prediksi sebelumnya menggunakan indeks terapi dan antimicrobial peptide database yang masih memberikan kemungkinan peptida LVNELTEFAK, HPYFYAPELLYYANK dan LANSTEFAK menjadi peptida antimikroba, dan perangkat lunak lain yang memprediksi bahwa peptida-peptida tersebut bukan antimikroba maka diperlukan perangkat lunak lebih dari satu untuk mendapatkan hasil prediksi yang lebih akurat. Hasil studi ini dapat digunakan sebagai dasar pemilihan perangkat lunak untuk kepentingan skrining peptida yang mempunyai 
aktivitas antimikroba, desain dan modifikasi peptida serta penemuan peptida antimikroba baru.

\section{KESIMPULAN}

Berdasarkan hasil studi yang telah dilakukan menunjukkan bahwa peptida derivat susu kuda sumbawa LVNELTEFAK, HPYFYAPELLYYANK dan LANSTEFAK tidak termasuk dalam kelompok peptida antimikroba. Perangkat lunak antimicrobial peptide scanner ver 2, iAMPpred dan CAMPr3 memberikan hasil prediksi yang mendekati kenyataan. Berdasarkan hasil tersebut, maka diperlukan lebih dari satu perangkat lunak untuk memperoleh prediksi yang lebih akurat. Hasil penelitian ini juga dapat digunakan sebagai dasar untuk skrining, desain dan penemuan antimikroba baru.

\section{DAFTAR PUSTAKA}

Badra P, Yan J, Li J, Fong S, Siu SW. 2018. AmPEP: Sequenced-based prediction of antimicrobial peptides using distribution patterns of amino acid properties and random forest. Nature. 8:1697

Cantor S, Vargas L, Rojas OE, Yarce CJ, Salamanca CH, Onate-Garzon J. 2019. Evaluation of the antimicrobial activity of cationic peptides loaded in surface-modified nanoliposomes against foodborne bacteria. Int J Mol Sci. 20:1-15.

Fernandez-Vidal M, Jayasinghe S, Ladokhin AS, White SH. 2007. Folding amphipathic helices into membranes: amphiphilicity trumphs hydrophobicity. J Mol Biol. 370:459470.

Henriksen JR, Etzerodt T, Gjetting T, Andresen TL. 2014. Side chain hydrophobicity modulates therapeutic activity and membrane selectivity of antimicrobial peptide mastoparan-X. PLoS ONE. 9:e91007.

Huang Y, He L, Li, G, Zhai N, Jiang H, Chen Y. 2014. Role of helicity of $\alpha$-helical antimicrobial peptides to improve specificity. Protein Cell. 5:631-642.

Huang YH, Huang JH, Chen Y. 2010. Alpha-helical cationic antimicrobial peptides: relationships of structure and function. Protein Cell. 1:143-152.

Jhong J, Chi Y, Li W, in T, Huang K, Lee T. 2019. dbAMP: an integrated resource for exploring antimicrobial peptides with functional activities and physicochemical properties on transcriptome and proteome data. Nucleic Acid Res. 47:D285-D297.

Juretic D, Vukicevic D, Ilic N, Antcheva N, Tossi A. 2009. Computational design of high selective antimicrobial peptides. J Chem Inf Model. 49:2873-2882.

Kamech N, Vukicevic D, Ladram A, Piesse C, Vasseur J, Bojovi V, Simunic J, Juretic D. 2012. Improving the selectivity of antimicrobial peptides from anuran skin. JCIM. 52:3341-3351.

Kusumaningtyas E, Widiastuti R, Kusumaningrum HD, Suhartono MT. 2016. Bioactivities and analysis peptide of Sumbawa horse milk generated by Bacillus thuringiensis protease. JITV. 21:144-254.

Kusumaningtyas E, Subekti DT, Fitaningtiyas DFL. 2019. Antimicrobial and antiinflammation activities of fraction and single peptides derived from mare milk protein. JITV. In Press 
Marr AK, Gooderham WJ, Hancock REW. 2006. Antibacterial peptides for therapeutic use: obstacles and realistic outlook. Curr Opin Pharmacol. 6:468-472.

Meher PK, Sahu TK, Saini V, Rao AR. 2017. Predicting antimicrobial peptides with accuracy by incorporating the compositional, physico-chemical and structural features into Chou's general PseACC. Sci Rep. 7:42362

Veltri D, Kamath U, Shehu A. 2018. Deep learning improves antimicrobial peptide recognition. Bioinformatics. 34:2740-2747.

Waghu FH, Barai RS, Gurung P, Idicula-Thomas S. 2015. CAMPR3: a database on sequences, structures and signatures of antimicrobial peptides. Nucleic Acids Res. gkv1051v1-gkv1051. Epub 2015 Oct 13.

Wang G, Li X, Wang Z. 2016. APD3: the antimicrobial peptide database as a tool for research and education. Nucleic Acids Res. 44:D1087-D1093. 